\title{
Effect of Colored Shading Nets on the Growth and Water Use Efficiency of Sweet Pepper Grown under Semi-arid Conditions
}

\author{
Osama Mohawesh ${ }^{1,2,4}$, Ammar Albalasmeh ${ }^{3}$, Sanjit Deb ${ }^{2}$, \\ Sukhbir Singh ${ }^{2}$, Catherine Simpson ${ }^{2}$, Nour AlKafaween ${ }^{1}$, and \\ Atif Mahadeen ${ }^{1}$
}

AdDITIONAL INDEX WORDs. abiotic stresses, Capsicum annum, climate change, gas exchange, yield quality

Summary. Colored shading nets have been increasingly studied in semi-arid crop production systems, primarily because of their ability to reduce solar radiation with the attendant reductions in air, plant, and soil temperatures. However, there is a paucity of research concerning the impact of colored shading nets on various crops grown under semi-arid environments, particularly the sweet pepper (Capsicum annum) production system. This study aimed to investigate the effects of three colored shading net treatments (i.e., white, green, and black shading nets with $50 \%$ shading intensity and control with unshaded conditions) on the growth and instantaneous water use efficiency (WUE) of sweet pepper. The results showed that all colored shading nets exhibited significantly lower daytime air temperatures and light intensity $\left(22\right.$ to $28^{\circ} \mathrm{C}$ and $9992 \mathrm{~lx}$, respectively) compared with the control ( 32 to $37^{\circ} \mathrm{C}$ and $24,973 \mathrm{~lx}$, respectively). There were significant differences in sweet pepper growth performance among treatments, including plant height, shoot dry weight, leaf area, leaf chlorophyll content, and vitamin $C$ in ripened fruit. The enhanced photosynthetic rates were observed in sweet pepper plants under the colored shading nets compared with control plants. WUE increased among the colored shading net treatments in the following order: control $\leq$ white $<$ black < green. Overall, the application of green and black shading nets to sweet pepper production systems under semi-arid environments significantly enhanced plant growth responses and WUE.

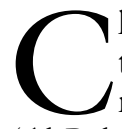
limate change has the potential to pose challenges to current methods of crop production (Al-Bakri et al., 2013; Meena et al., 2014). Unless additional protective measures are taken, higher temperatures may affect crop growth and performance, including the appearance of abiotic disorders (Ilić et al., 2017) and limited productivity (Flaishman et al., 2015). Sweet pepper (Capsicum annum) is an important crop in Jordan. It is generally produced in Jordan Valley, which has been negatively affected by increasing temperatures over the years (Al-Bakri et al., 2013). In addition to exporting this crop to other countries, most Jordanian people use sweet pepper for food, spices, and other applications. However, the production of this essential crop is becoming threatened by weather extremes. One of the solutions to alleviate the effects of high temperature in crop production systems is to manipulate plant development and growth using shading screens or nets
(Díaz-Pérez, 2013). Growers have increasingly used this low-cost technique in many countries during the past decade (Ilić et al., 2017).

As plants respond to light quantity, quality, direction, and periodicity, the use of shading nets can reduce solar radiation and affect light quality by increasing the relative proportion of diffused light and absorbing various spectral bands (Stamps, 2009). At the same time, the shading nets can act as physical protection against birds and insects (Kittas et al., 2014). Shading nets can be used alone as a cover, or they can be integrated with existing greenhouse technologies (Shahak et al., 2004). The netting materials can also be modified during manufacturing by adding chromatic additives and reflective and/or light dispersive elements (Shahak et al., 2004). Additionally, the colored shading nets can increase the relative amount of dispersed light, absorb various spectral bands, and modify the light environment (Stamps, 2009). Diffracted light breaches more intensely and efficiently into plant canopies, which has prompted much attention because of its importance to shading technology in crop production systems (Kittas et al., 2012). Furthermore, this low-cost protected cultivation technique has the ability to lessen environmental stresses (biotic and abiotic), which can ultimately improve plant growth and yield (Kittas et al., 2012).

Water resources in Jordan and in the Mediterranean region are very limited, and the climate is characterized by hot summers, high solar radiation, and dry weather. Under such stressful environments, there is an ever-increasing need to improve and understand environmental controls that can enhance plant growth and production (Ilić et al., 2017). The extreme variabilities in air temperatures and solar radiation during the crop growing seasons have been shown to be vital to plant growth and yield (Caruso et al., 2020). However, only solar radiation intercepted by the crop can contribute to photosynthesis (Díaz-Pérez, 2013). The chloroplast pigment content and photosynthetic processes of the plant were

\begin{tabular}{lllc}
\hline $\begin{array}{l}\text { Units } \\
\text { To convert U.S. to SI, } \\
\text { multiply by }\end{array}$ & U.S. unit & SI unit & $\begin{array}{l}\text { To convert SI to U.S., } \\
\text { multiply by }\end{array}$ \\
\hline 10.7639 & $\mathrm{fc}$ & $\mathrm{lx}$ & 0.0929 \\
0.3048 & $\mathrm{ft}$ & $\mathrm{m}$ & 3.2808 \\
0.0929 & $\mathrm{ft}^{2}$ & $\mathrm{~m}^{2}$ & 10.7639 \\
2.54 & inch $(\mathrm{es})$ & $\mathrm{cm}^{2}$ & 0.3937 \\
6.4516 & inch $^{2}$ & $\mathrm{~cm}^{2}$ & 0.1550 \\
16.3871 & $\mathrm{inch}^{3}$ & $\mathrm{~cm}^{3}$ & 0.0610 \\
1.1209 & lb/acre & $\mathrm{kg} \cdot \mathrm{ha}^{-1}$ & 0.8922 \\
1 & $\mathrm{mmho} / \mathrm{cm}$ & $\mathrm{dS} \cdot \mathrm{m}^{-1}$ & 1 \\
28.3495 & $\mathrm{oz}$ & $\mathrm{g}$ & 0.0353 \\
0.1 & $\mathrm{ppm}$ & $\mathrm{mg} / 100 \mathrm{~g}$ & 10 \\
1 & $\mathrm{ppm}$ & $\mathrm{mg} \cdot \mathrm{kg}^{-1}$ & 1 \\
0.0069 & $\mathrm{psi}$ & $\mathrm{MPa}$ & 145.0377 \\
2.2417 & ton $(\mathrm{s}) / \mathrm{acre}$ & $\mathrm{t} \cdot \mathrm{ha}^{-1}$ & 0.4461 \\
$\left({ }^{\circ} \mathrm{F}-32\right) \div 1.8$ & ${ }^{\circ} \mathrm{F}$ & ${ }^{\circ} \mathrm{C}$ & $\left({ }^{\circ} \mathrm{C} \times 1.8\right)+32$ \\
& & &
\end{tabular}


improved as shading levels were increased (Kittas et al., 2012).

Colored shading nets were designed to manipulate plant growth and development by affecting the numerous photoreceptors in plants (Folta and Maruhnich, 2007). The use of shading nets, specifically colored shading nets in arid and semi-arid regions where crops are exposed to high air temperatures and solar radiation, is becoming increasingly important to ensure high quality and yields (Kittas et al., 2014). Ilić et al. (2017) reported a significant increase in the total fruit yield (higher by $113 \%$ to $131 \%$ ) of tomato (Solanum lycopersicum) under colored shading nets (pearl, blue, red) compared with the conventional black shading nets. Similarly, Shahak (2014) and Fallik et al. (2009) reported an increase in sweet pepper yield under colored shading nets compared with the black shading net. Moreover, Goren et al. (2011) reported a decrease in decay incidence under 35\% pearl and yellow shading nets compared with black and red shading nets. Although the black shading net is the most commonly used worldwide, there has been an increased interest in different colored shading nets to improve plant growth, yield, and quality (DíazPérez, 2013; Ilić et al., 2017). Moreover, the use of colored shading nets has been shown to be a feasible option to increase WUE and enhance plant

Received for publication 27 July 2021. Accepted for publication 22 Aug. 2021.

Published online 14 December 2021.

${ }^{1}$ Department of Plant Production, Faculty of Agriculture, Mutah University, P.O. Box 7, Karak 61710, Jordan

${ }^{2}$ Department of Plant and Soil Science, Texas Tech University, Lubbock, TX 79409-2122

${ }^{3}$ Department of Natural Resources and Environment, Jordan University of Science and Technology, Irbid, Jordan

${ }^{4}$ Visiting Professor, Texas Tech University, Lubbock, TX 79409-2122

We gratefully acknowledge support from the Dean ship of Scientific Research at Mutah University, Jordan, when conducting this research. The manuscript was prepared and finalized while the first author was supported by the Fulbright Visiting Scholar Award. We thank Dr. Ibrahim Makhadmeh (Department of Plant Production, Jordan University of Science and Technology) and Dr. Rupinder Saini (Department of Plant and Soil Science, Texas Tech University) for their helpful suggestions regarding previous drafts of the manuscript.

O.M. is the corresponding author. E-mail: osama@ mutah.edu.jo.

This is an open access article distributed under the CC BY-NC-ND license (https://creativecommons. org/licenses/by-nc-nd/4.0/).

https://doi.org/10.21273/HORTTECH04895-21 growth. Despite the colored shading nets showed benefits in some crops, information on the effects of different colored nets on various crops is still limited. Therefore, the objective of this study was to assess the impact of different colored shading nets on sweet pepper growth performance and WUE under semi-arid conditions.

\section{Materials and methods}

EXPERIMENTAL SITE AND LAYOUT. This field experiment was conducted at the College of Agriculture experimental station, Mutah University, Karak governate, Jordan (lat. $31^{\circ} 16^{\prime} \mathrm{N}$, long. $35^{\circ} 45^{\prime} \mathrm{E}$; elevation $920 \mathrm{~m}$ ) from June to Oct. 2017. The average temperature and rainfall were $21^{\circ} \mathrm{C}$ and $250 \mathrm{~mm}$, respectively, during the growing season. The soil is red Mediterranean soil (terra rosa) and classified as clay loam soil $[$ clay $=37.9 \%$; silt $=26.7 \%$; sand $=$ $35.4 \%$; electrical conductivity (EC) $=$ $1.04 \mathrm{dS} \cdot \mathrm{m}^{-1} ; \mathrm{pH}=7.9 ;$ nitrogen $(\mathrm{N})=265$ ppm; phosphorus $(\mathrm{P})=55$ ppm; potassium $(\mathrm{K})=219 \mathrm{ppm}]$. The experiment had four treatments: three colored shading nets (white, green, and black shading nets) and a control (unshaded conditions). The experiment was designed as a randomized complete block design with three replications of each treatment. Each block with an area of $40 \mathrm{~m}^{2}$ consisted of four plots (white, green, black, and control). Each treatment plot with an area of $7.5 \mathrm{~m}^{2}$ consisted of four 5 - $\mathrm{m}$-long rows spaced 1.5 $\mathrm{m}$ apart under each shading cloth structure for each plot. A spacing of $1.0 \mathrm{~m}$ was used as a buffer zone between the treatment plots within the blocks. The shading nets were mounted on a steel structure (north-south direction) $\approx 2.0$ $\mathrm{m}$ in height over the plants. To investigate the effects of shading nets, three colored shading nets (white, green, and black) were used with a shading intensity of $50 \%$ relative shading. The colored shading nets were obtained from Qetaf Jordan Agriculture Investments Co. Plastics Industries (Amman, Jordan). The functions of photo-selective shading nets depend on the incorporation of several chromatic additives and light dispersive and reflective elements into the netting materials during manufacturing (Díaz-Pérez, 2013).

Planting and growth PERforMANCE ANALYsis. Plowing, disking, and leveling were performed to prepare the site for planting. Decomposed chicken manure $\left(\mathrm{l} t \cdot \mathrm{ha}^{-1}\right)$ was applied during the land preparation. The raised beds $(0.6 \mathrm{~m}$ wide and $0.2 \mathrm{~m}$ tall $)$ were then prepared. A drip irrigation system was installed to irrigate the seedlings. A single row of plants was grown in the middle of plastic mulch with a single lateral for each row and one drip emitter per plant to distribute water over the soil surface around the plant. 'Kentucky' sweet pepper (Bayer, Amman, Jordan) plants were transplanted on 15 June 2017 , with spacing of 40 $\mathrm{cm}$ between plants under the shading nets, which were installed before transplanting the seedlings (50 plants per plot). The growing season for sweet pepper plants was 5 months (i.e., from June to October). At the maximum growth stage of sweet pepper plants (early September), the plant height, leaf area (LA), leaf water potential, and leaf mineral contents were measured for each treatment in triplicate. Three measurements were taken from each plot. In total, we had nine measurements for each measured parameter. The plant height was measured with a ruler for each treatment in triplicate. The measurement of LA was performed using the photoelectrical method for each treatment in triplicate. Midday leaf water potential (LWP) was measured using a pressure chamber technique (PMS Instruments Co., Albany, OR) (Mohawesh, 2016) in triplicate. Selected leaves (same age) were selected from each treatment for triplicate assays. Three separate leaves (same age) were dried at $75^{\circ} \mathrm{C}$ for $\mathrm{l}$ week and then ground. These ground samples were used to determine $\mathrm{N}, \mathrm{P}$, $\mathrm{K}$, and calcium $(\mathrm{Ca})$. The spectrophotometer (ultraviolet-1601PC; Shimadzu, Kyoto, Japan) was used for the quantitative analysis of $\mathrm{P}$ in samples using the method proposed by Watanabe and Olsen (1965), whereas the atomic absorption spectrometer was used to determine $\mathrm{Ca}$ and $\mathrm{K}$ (Mohawesh, 2016). Total $\mathrm{N}$ was determined using the Kjeldahl method described in the work by Mohawesh et al. (2019). The chlorophyll content in plants was determined for a fully expanded, healthy leaf from each plant using a chlorophyll meter (SPAD-502; Konica Minolta Sensing, Osaka, Japan) in triplicate (Alamro et al., 2019). Ripened fruit (colored red) was harvested at the end of the growing season on 20 Oct. 2017 for vitamin C determination. 
The quantitative analysis of vitamin C (ascorbic acid) was performed using the procedure described by Sadasivam and Manickam (1992). Photosynthetic $(\mathrm{Pn})$ and transpiration rates $(\mathrm{E})$ were measured in developed leaves (three per plant on the third or fourth pair of leaves from the tip of a shoot) using a portable photosynthesis system (CI340; CID Bio-Science, Camas, WA). Measurements of Pn and E were performed once every 2 weeks, starting $\approx 30 \mathrm{~d}$ after transplanting for each treatment in triplicate. At the end of the experiment (25 Oct. 2017), the plants from each plot were cut at their bases, and roots were carefully washed with tap water to minimize root damage and loss for each treatment in triplicate. Extra water was removed from samples with paper towels. Shoot and root fresh weights were recorded after weighing them on a scale $( \pm 0.01 \mathrm{~g})$ at room temperature. Then, all the shoot and root samples were dried at $75^{\circ} \mathrm{C}$ for $5 \mathrm{~d}$ to determine their dry weights.

SOIL SAMPLING AND ANALYSIS. At the beginning of the experiment, soil samples were collected from the experimental field to determine soil physicochemical properties. Soil properties were analyzed based on the standard procedures described by Klute (1986). Soil water content for each treatment plot was recorded at 2-d intervals using a handheld time domain reflectometer (ThetaProbe, ML2x; Delta-T Devices, Cambridge, UK) in triplicate at a 15$\mathrm{cm}$ soil depth between plants. Additionally, tensiometers (Irrometer Co. Inc., Riverside, CA) were used to obtain routine measurements of soil matric potentials at 2-d intervals for each treatment plot. Soil temperatures for each treatment plot were measured every week using thermometers that were inserted in the soil down to a depth of $15 \mathrm{~cm}$ during the measurement.

IRRIGATION, FERTILIZATION, AND MICROENVIRONMENT MEASUREMENTS. Irrigation was applied when the soil water content level in the root zone reached $50 \%$ of the plant's available water (i.e., the difference between field capacity and permanent wilting point water contents). The amount of irrigation and time for the shading treatments were adjusted manually based on the soil water content and soil matric potential to achieve field capacity soil water content after each irrigation event. Fertilizer $(20 \mathrm{~N}-8.8 \mathrm{P}-16.6 \mathrm{~K})$ was added through irrigation during the growing season from June to Oct. 2017. Sweet pepper plants were fertigated four times (the fertilizer amount was split equally once per month) during the growing season. Fertilizers with a total of 250 $\mathrm{kg} \cdot \mathrm{ha}^{-1}$ urea $(46 \% \mathrm{~N}), 150 \mathrm{~kg} \cdot \mathrm{ha}^{-1}$ ammonium sulfate, and $520 \mathrm{~kg} \cdot \mathrm{ha}^{-1}$ $20 \mathrm{~N}-8.8 \mathrm{P}-16.6 \mathrm{~K}$ (with trace elements) were applied following the recommendations of Mohawesh (2016). Detailed information regarding the irrigation and fertigation system used during this study can be found in the work by Mohawesh (2016). The effects of shading nets on the interception of light were determined using temperature/light data loggers (HOBO Pendant; Onset Computer Corp., Bourne, MA) mounted 50 $\mathrm{cm}$ below the shading cloth $(150 \mathrm{~cm}$ above the soil surface). These air temperature and light intensity data were collected at 10 -min intervals throughout the crop growing period.

Statistical anAlysis. Data were analyzed using the General Linear Model procedure and statistical software (SPSS version 11.5; IBM Corp., Armonk, NY). The least significant difference test at $P \leq 0.05$ was used for mean separation.

\section{Results and discussion}

EFFECTS OF COLORED SHADING NETS ON AIR TEMPERATURE AND LIGHT INTENSITY. Figure 1 shows the differences in daytime air temperatures among the treatments. The daytime air temperature showed statistically significant differences between the colored shading treatments and the control. Moreover, the black shading net showed significantly lower air temperatures compared with other shading treatments (white and green). Shading contributed to reflecting solar radiation and lowering the heat dispersion, thereby reducing the air temperature under the colored shading net treatments, which agrees with Díaz-Pérez (2013), who suggested shading nets promote temperature reduction. Our results agreed with those of a previous work in which lower air temperature under the shading net treatments was observed compared with the treatment with no shading nets (Ilić et al., 2017).

Under the colored shading nets, part of the solar radiation is absorbed, whereas the rest is reflected (DíazPérez, 2013). As shown in Fig. 2, the light intensity under the control was significantly higher $(P=0.03)$ than that for the colored shading net treatments. In addition, although lower than that of the control, light intensity was not significantly different among the three colored shading nets (Fig. 2). This suggests that the light intensity under colored shading nets plays a role in microclimate regulation (Meena et al., 2014).

EFFECTS OF THE COLORED SHADING NETS ON SOIL TEMPERATURE, SOIL WATER CONTENT, AND SOIL MATRIC POTENTIAL. Weekly soil temperature variations under the colored shading nets and control are shown in Fig. 3. Soil temperatures within the upper $15-\mathrm{cm}$ soil depth were lower and more stable under the colored shading nets compared with those of the control. Soil temperatures varied from 19 to $23^{\circ} \mathrm{C}$ for colored shading treatments

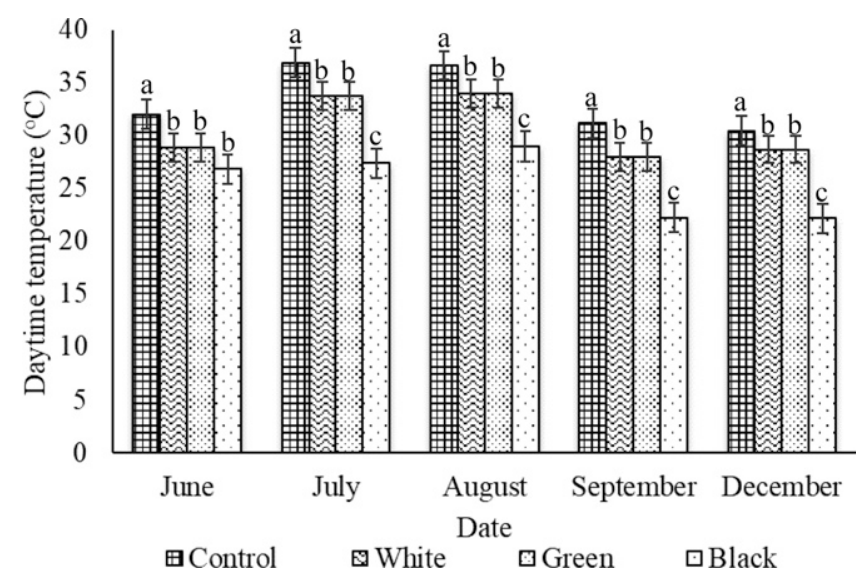

Fig. 1. Effects of different colored shading net treatments on air temperature during the experimental period (June-Oct. 2017). Different lowercase letters represent a significant difference between shading treatments $(P \leq 0.05)$ on the same date. $\left(1.8 \times{ }^{\circ} \mathrm{C}\right)+32={ }^{\circ} \mathrm{F}$. 


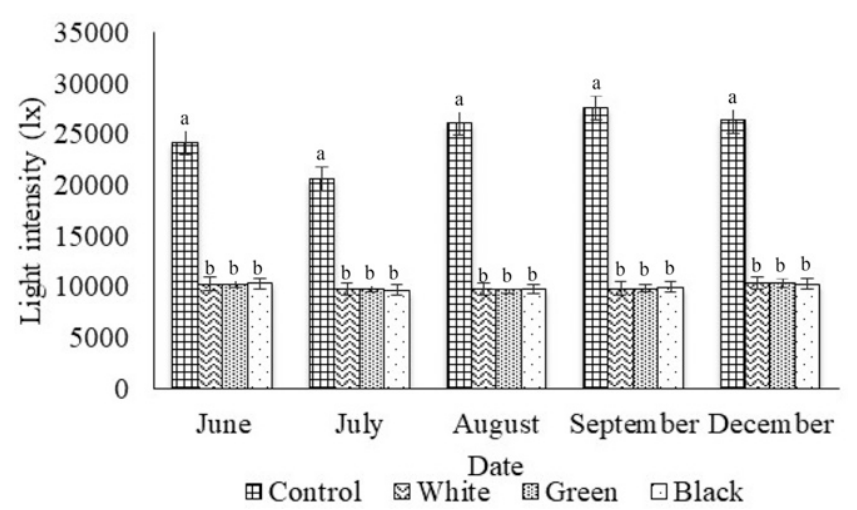

Fig. 2. Effects of different colored shading net treatments on light intensity during the experimental period (June-Oct. 2017). Different letters represent a significant difference between shading treatments $(P \leq 0.05)$ on the same date. $1 \mathrm{~lx}=0.0929 \mathrm{fc}$. compared with those of the unshaded control, for which soil temperatures varied between 19 and $25.5^{\circ} \mathrm{C}$ during the experimental period. These differences could be attributed to the colored shading reflecting solar radiation, reducing the radiant flux reaching the soil, and regulating microclimatic temperatures to provide the crops with more optimal soil temperature conditions for enhanced crop growth and development (Meena et al., 2014).

The soil under the colored shading nets had higher soil water content compared with that of the control (Fig. 4). Colored shading nets likely reduced microclimatic plants' ambient temperatures, resulting in the reduction of leaf transpiration (Díaz-Pérez, 2013). Moreover, the reductions in evaporation and transpiration could have resulted from the lessened air movement and evaporative demand under the colored shading net treatments. Our results were similar to those of previous research during which reduced evapotranspiration (i.e.,

soil evaporation and plant transpiration) was observed under shading nets (Kittas et al., 2014). The effects of shading nets on enhanced soil water content or soil water potential as well as water use efficiency have been reported by different studies. For instance, Möller and Assouline (2007) concluded that $30 \%$ black shading net reduced solar radiation and increased irrigation water use efficiency of bell pepper. Díaz-Pérez (2013) observed higher (i.e., less negative) soil matric potential values or enhanced soil water conditions under the shading nets compared with the control; these facilitated lower soil temperatures and favored reductions in soil evaporation.

EFFECTS OF THE COLORED SHADING NETS ON SWEET PEPPER GROWTH PERFORMANCE. The results presented demonstrate the effects of colored shading nets on shoot fresh and dry weights and root fresh and dry weights of sweet pepper plants. There are significant differences between fresh and dry weights of sweet pepper shoots

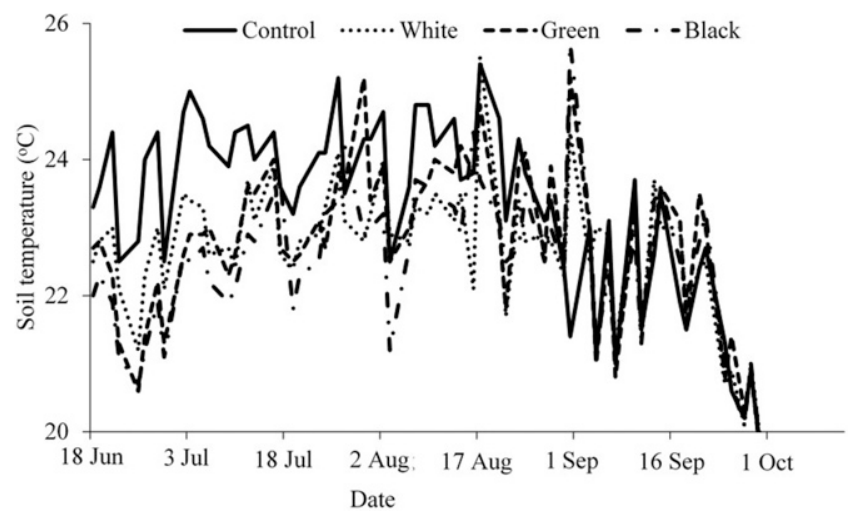

Fig. 3. Soil temperatures under different colored shading net treatments during the experimental period (June-Oct. 2017). $\left(1.8 \times{ }^{\circ} \mathrm{C}\right)+32={ }^{\circ} \mathrm{F}$. among the treatments, and the white shading net treatment showed the highest values (i.e., shoot fresh and dry weights of 310 and $58.8 \mathrm{~g}$, respectively). However, there were no significant differences in root fresh and dry weights of sweet pepper plants among the treatments (Table 1).

Plants grown under colored shading nets were significantly $(P=0.04)$ taller than those of the control. However, among the colored shading net treatments, the black shading nets resulted in significantly greater height (Table 2). However, as shown in Fig. 2, the light intensity underneath the shading nets was not significantly different between netting treatments, suggesting that another value of light quality may have a role in stem elongation. The most plausible explanation for significantly greater plant height under the black shading nets, even with no statistical difference in light intensity, might be related to differences in the light spectrum under different shading (Möller and Assouline, 2007; Rylski and Spigelman, 1986).

There was a significant difference in LA among the treatments (Table 2). Our results showed that all colored shading nets (white, green, black) had significantly higher LA compared with that of the control, with LA of $8.9 \mathrm{~cm}^{2}$. These results were in line with the findings from a study by Tinyane et al. (2013) during which higher LA was observed for tomato grown under the shading nets. This was most likely the result of cell expansion to compensate for the lower light under shading environments to receive more light for photosynthetic processes. Our results also agree with those of Kittas et al. (2014) and Díaz-Pérez (2013), who showed longer internodes and larger LA for tomato and bell pepper under shading nets. Similarly, Ilić et al. (2017) also observed that the LA index was significantly higher under shade nets compared with no shading (control).

Although it was postulated that colored shading nets would improve the quantity of chlorophyll and, hence, would increase photosynthetic efficiency, resulting in increased yield, our results revealed that chlorophyll content under colored shading nets did not significantly differ from that of the control, except for the chlorophyll content under black shading nets (Table 2). The shaded leaves under the 


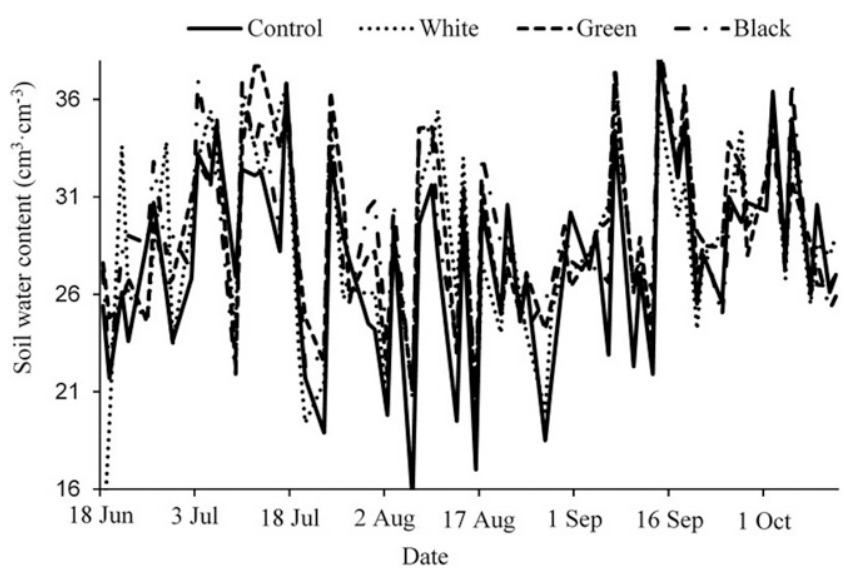

Fig. 4. Effects of different colored shading nets on soil water content during the experimental period (June-Oct. 2017). $1 \mathrm{~cm}^{3}=0.0610 \mathrm{inch}^{3}$.

black shading nets were more likely to be thinner leaves that could contain larger pigment-rich chloroplasts, as discussed by Ilić et al., (2017) and Mupambia et al., (2018). The higher chlorophyll content under black shading nets can be related to higher photosynthetically active radiation $(P A R)$, as reported by (Ntsoane, 2015). There was a significant effect of colored shading net treatments on LWP values (Table 2). The control treatment had a more negative value of $-1.6 \mathrm{MPa}$, suggesting relatively more plant water stress as compared with the colored shading net treatments. This is likely because of the increased light and temperature under the unshaded control, which contributed to an increase in soil water evaporation as well as plant transpiration (Mohawesh, 2016).

The colored shading net treatments should have an overall negative effect on the vitamin $\mathrm{C}$ content in

Table 1. Effects of the colored shading net (with $50 \%$ shading intensity) on sweet pepper mean shoot fresh weight (SFW), shoot dry weight (SDW), root fresh weight (RFW), and root dry weight (RDW) at 16 weeks after transplanting (15 June 2017).

\begin{tabular}{lllcl}
\hline & SFW $(\mathrm{g})$ & SDW $(\mathrm{g})$ & RFW $(\mathrm{g})$ & RDW $(\mathrm{g})$ \\
\cline { 2 - 5 } Shading treatment & \multicolumn{4}{c}{ Mean \pm SD $^{\mathrm{z}}$} \\
\hline Control & $187 \pm 8.3 \mathrm{c}^{\mathrm{y}}$ & $35 \pm 2.5 \mathrm{c}$ & $22 \pm 1.6 \mathrm{a}$ & $11 \pm 0.9 \mathrm{a}$ \\
White & $310 \pm 5.6 \mathrm{a}$ & $58 \pm 3.4 \mathrm{a}$ & $18 \pm 2.8 \mathrm{a}$ & $10 \pm 1.3 \mathrm{a}$ \\
Green & $282 \pm 7.2 \mathrm{ab}$ & $47 \pm 4.1 \mathrm{~b}$ & $26 \pm 3.7 \mathrm{a}$ & $15 \pm 1.8 \mathrm{a}$ \\
Black & $238 \pm 11.4 \mathrm{~b}$ & $46 \pm 5.7 \mathrm{~b}$ & $18 \pm 4.3 \mathrm{a}$ & $11 \pm 1.1 \mathrm{a}$ \\
\hline
\end{tabular}

${ }^{\mathrm{z}} 1 \mathrm{~g}=0.0353 \mathrm{oz}$.

${ }^{\mathrm{y}}$ Different lowercase letters in the same column for each plant trait indicate significant differences according to the least significant difference test $(P \leq 0.05)$.

ripened fruit (Table 2). Higher concentrations of vitamin $\mathrm{C}$ under higher light intensities can be related to the ascorbic acid role in preventing abiotic plant injuries (Ntsoane, 2015). However, vitamin $\mathrm{C}$ content in fruit under the colored shading nets was not significantly different from that of the control, except for vitamin C contents $(90.9 \mathrm{mg} / \mathrm{l} 00 \mathrm{~g})$ under the black shading nets. This could be explained by the need for light to synthesize vitamin $\mathrm{C}$ content with moderate temperatures under the black shading net treatment. These results are consistent with those of previous studies (Buthelezi et al., 2016; Ntsoane, 2015 ) in which increases in vitamin C content found under black shading nets have been reported. The higher vitamin $\mathrm{C}$ content under black shading nets can be related to higher $P A R$ under black shading nets, as reported by Ntsoane (2015). There was no significant influence of shading treatments on the leaf mineral contents (i.e., N, P, K, and Ca) of sweet pepper in this experiment (Table 3). This result agrees with that of Caruso et al. (2020), who found that the mineral composition of the shaded perennial wall rocket (Diplotaxis tenuifolia) plants was not significantly different from that of the unshaded crops.

EFFECTS OF THE COLORED SHADING NETS ON PLANT GAS EXCHANGE. Leaf functional traits are important because they reflect physiological functions, such as $\mathrm{Pn}, \mathrm{E}$, and carbon assimilation of plants. There was a statistically significant difference in the Pn between the colored shading net treatments and the control treatment (Fig. 5A). However, the Pn in sweet pepper plants under the white net was not consistently higher than that in control plants over time

Table 2. Effects of the colored shading net (with $50 \%$ shading intensity) on sweet pepper mean plant height, leaf area (LA), chlorophyll content, and leaf water potential (LWP) at the maximum growth stage (11-12 weeks) after transplanting on 15 June 2017. Chlorophyll content in plants represents the average weekly measured data after 1 month of transplanting, whereas fruit vitamin $\mathrm{C}$ content was measured at the end of the growing season.

\begin{tabular}{|c|c|c|c|c|c|}
\hline & $\underline{\text { Plant ht }(\mathrm{cm})^{\mathrm{z}}}$ & LA $\left(\mathrm{cm}^{2}\right)^{\mathrm{z}}$ & $\begin{array}{l}\text { Chlorophyll } \\
\text { (SPAD unit) }\end{array}$ & $\operatorname{LWP}(\mathbf{M P a})^{\mathrm{z}}$ & $\begin{array}{c}\text { Vitamin } C \\
(\mathrm{mg} / 100 \mathrm{~g})^{\mathrm{z}}\end{array}$ \\
\hline Shading treatment & \multicolumn{5}{|c|}{ Mean \pm SD } \\
\hline White & $109 \pm 11.2 \mathrm{~b}$ & $15.8 \pm 1.9 \mathrm{a}$ & $54 \pm 2.1 \mathrm{~b}$ & $-1.3 \pm 0.8 b$ & $47 \pm 10.2 \mathrm{~b}$ \\
\hline Green & $106 \pm 8.4 \mathrm{~b}$ & $15.5 \pm 3.1 \mathrm{ab}$ & $54 \pm 0.8 \mathrm{~b}$ & $-1.5 \pm 0.8 \mathrm{ab}$ & $58 \pm 11.3 \mathrm{~b}$ \\
\hline Black & $117 \pm 5.8 \mathrm{a}$ & $12.8 \pm 2 b$ & $56 \pm 1.2 \mathrm{a}$ & $-1.5 \pm 1.2 \mathrm{ab}$ & $91 \pm 7.9 \mathrm{a}$ \\
\hline
\end{tabular}

${ }^{\mathrm{z}} 1 \mathrm{~cm}=0.3937$ inch; $1 \mathrm{~cm}^{2}=0.1550$ inch $^{2} ; 1 \mathrm{MPa}=145.0377 \mathrm{psi}$; and $1 \mathrm{mg} / 100 \mathrm{~g}=10 \mathrm{ppm}$.

${ }^{\mathrm{y}}$ Different lowercase letters in the same column for each plant trait indicate significant differences according to the least significant difference test $(P \leq 0.05)$.

SPAD = Soil Plant Analysis Development. 
Table 3. Effects of colored shading net (with $50 \%$ shading intensity) on sweet pepper leaf nitrogen $(\mathrm{N})$, phosphorus $(\mathrm{P})$, potassium $(\mathrm{K})$, and calcium $(\mathrm{Ca})$ content at the maximum growth stage (11-12 weeks) after transplanting on 15 June 2017.

\begin{tabular}{llllr}
\hline & \multicolumn{1}{c}{$\mathbf{N}(\%)$} & \multicolumn{1}{c}{$\mathbf{P}(\mathbf{p p m})^{\mathrm{z}}$} & \multicolumn{4}{c}{$\mathrm{K}(\mathrm{ppm})$} & $\mathrm{Ca}(\mathrm{ppm})$ \\
\cline { 2 - 5 } Shading treatment & \multicolumn{4}{c}{ Mean $\pm \mathrm{sD}$} \\
\hline Control & $6.4 \pm 0.16 \mathrm{a}^{\mathrm{y}}$ & $1318 \pm 47 \mathrm{a}$ & $15,398 \pm 420 \mathrm{a}$ & $9129 \pm 259 \mathrm{c}$ \\
White & $7.3 \pm 1.2 \mathrm{a}$ & $1245 \pm 68 \mathrm{a}$ & $18,362 \pm 981 \mathrm{a}$ & $3286 \pm 725 \mathrm{a}$ \\
Green & $6.6 \pm 2.1 \mathrm{a}$ & $1296 \pm 147 \mathrm{a}$ & $17,852 \pm 741 \mathrm{a}$ & $11,444 \pm 1014 \mathrm{~b}$ \\
Black & $7.1 \pm 0.5 \mathrm{a}$ & $1401 \pm 97 \mathrm{a}$ & $16,910 \pm 1140 \mathrm{a}$ & $11,457 \pm 658 \mathrm{~b}$ \\
\hline
\end{tabular}

${ }^{\mathrm{z}} \mathrm{l} \mathrm{ppm}=1 \mathrm{mg} \cdot \mathrm{kg}^{-1}$.

yifferent lowercase letters in the same column for each plant trait indicate significant differences according to the least significant difference test $(P \leq 0.05)$.
(Fig. 5A). As mentioned, the colored shading net regulated microclimatic soil and air temperatures and light (light spectrum), leading to higher soil water contents and lower soil evaporation and/or $\mathrm{E}$ under the shading treatments as compared with those of the control with unshaded conditions
(Fig. 5B). The effects of colored shading nets on the microclimate of plants might differ because Pn, E, and WUE varied among the shading treatments (Ntsoane, 2015). The reduction in leaf $\mathrm{E}$ (i.e., reduction in the plant water uptake) and the increase in the soil water content could be explained by
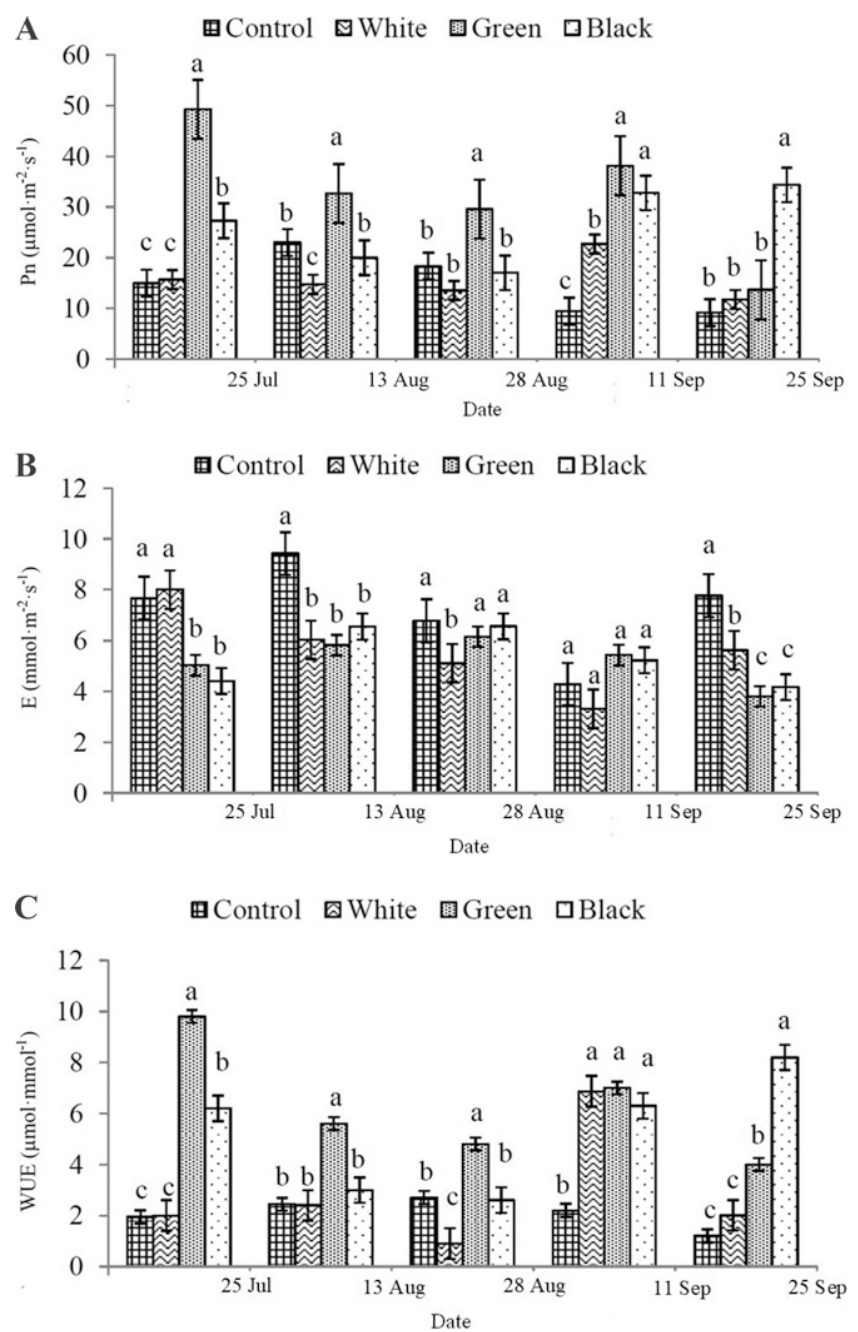

Fig. 5. Effects of colored shading net on sweet pepper (A) photosynthesis (Pn), (B) transpiration (E), and (C) water use efficiency (WUE) during the experimental period (June-Oct. 2017). Different lowercase letters represent a significant difference between shading treatments $(P \leq 0.05)$ on the same date. the reduced microclimatic temperatures under the colored shading net (Fig. 1), resulting in the reduced evaporative demand. The instantaneous WUE of sweet pepper under the colored shading net was significantly different from that of the control depending on the growing season period (Fig. 5C). Specifically, WUE under the green and black colored shading nets was higher compared with that of the unshaded control. These results further confirmed that colored shading nets could help reduce water stress and enhance WUE in semi-arid crop production systems (Mohawesh and Karajeh, 2014).

In conclusion, our results showed that in sweet pepper production systems, the use of colored shading nets (white, green, and black) resulted in significantly lower solar radiation intensity, light intensity, and daytime temperatures compared with those of the control treatment with unshaded conditions. Accordingly, the soil under the colored shading net treatments had higher soil water content for optimal plant growth, which was most likely attributable to reduced evaporation and transpiration under these shading net treatments. Compared with the unshaded control, the plants grown under colored shading net treatments had significantly greater plant height, shoot fresh and dry weights, and LA. The enhanced chlorophyll content in plants under the colored shading net treatments further underscored the improved sweet pepper growth performance. The mid-day leaf water potential measurements revealed that there was significantly more plant water stress under the unshaded control as compared with that under the colored shading nets. The WUE under the green and black colored shading nets was higher compared with that of the unshaded control. Overall, our results suggest using different colored shading nets, especially green and black, for sweet pepper production systems in arid and semi-arid environments, such as in Jordan, can significantly enhance plant growth responses and WUE. However, further evaluations of these colored shading nets and shading percentages for multiple sweet pepper growing seasons are suggested.

\section{Literature cited}

Alamro, M., A. Mahadeen, and O. Mohawesh. 2019. Effect of degradable 
mulch on tomato growth and yield under field conditions. Bulg. J. Agr. Sci. 25: 1122-1132.

Al-Bakri, J., M. Salahat, A. Suleiman, M. Suifan, M. Hamdan, S. Khresat, and T. Kandakji. 2013. Impact of climate and land use changes on water and food security in Jordan: Implications for transcending "The tragedy of the commons." Sustainability 5:724-748, https://doi.org/10.3390/su 5020724 .

Buthelezi, M., P. Soundy, J. Jifon, and D. Sivakumar. 2016. Spectral quality of photo-selective nets improves phytochemicals and aroma volatiles in coriander leaves (Coriandrum sativum) after postharvest storage. J. Photochem. Photobiol. Bol. Biol. 161:328-334, https://doi.org/ 10.1016/j.jphotobiol.2016.05.032.

Caruso, G., L. Formisano, E. Cozzolino, A. Pannico, C. El-Nakhel, Y. Rouphael, A. Tallarita, V. Cenvinzo, and S. De Pascale. 2020. Shading affects yield, elemental composition and antioxidants of perennial wall rocket crops grown from spring to summer in southern Italy. Plants 9:933, https:// doi.org/10.3390/plants9080933.

Díaz-Pérez, J.C. 2013. Bell pepper (Capsicum annum) crop as affected by shade level: Microenvironment, plant growth, leaf gas exchange, and leaf mineral nutrient concentration. HortScience 48:175-182, https:// doi.org/10.21273/HORTSCI.48.2.175.

Fallik, E., S. Alkalai-Tuvia, Y. Parselan, Z. Aharon, A. Elmann, Y. Offir, E. Matan, H. Yehezkel, K. Ratner, N. Zur, and Y. Shahak. 2009. Can colored shade nets maintain sweet pepper quality during storage and marketing? Acta Hort. 830:37-44, https://doi. org/10.17660/ActaHortic.2009.830.3.

Flaishman, M.A., Y. Peles, Y. Dahan, S. Milo-Cochavi, A. Frieman, and A. Naor. 2015. Differential response of cell cycle and cell-expansion regulators to heat stress in apple (Malus domestica) fruitlets. Plant Sci. 233:82-89, https://doi.org/10.1016/j. plantsci.2015.01.005.

Folta, K.M. and S.A. Maruhnich. 2007. Green light: A signal to slow down or stop. J. Expt. Bot. 58:3099-3111, https://doi. org/10.1093/jxb/erml30.

Goren, A., S. Alkalai-Tuvia, Y. Perzelan, E. Fallik, and Z. Aharon. 2011. Photoselective shade nets reduce postharvest decay development in pepper fruits. Adv. Hort. Sci.
25:26-31. http://lib-e2.lib.ttu.edu/login? url=https: / /www.jstor.org/stable $/ 4288$ 2805.

Ilić, Z.S., L. Mienkovici, L. Sunici, S. Baraci, J. Mastilovic, Z. Kevresan, and E. Fallik. 2017. Effect of shading by coloured nets on yield and fruit quality of sweet pepper. Zemdirbyste 104:53-62, https://doi.org/ 10.13080/z-a.2017.104.008.

Kittas, E., N. Katsoulas, A. Kandila, M.M. González-real, and A. Baille. 2014. Photosynthetic acclimation of sweet pepper plants to screen house conditions. HortScience 49:166-172, https://doi.org/10.21273/ HORTSCI.49.2.166.

Kittas, C., N. Katsoulas, N. Rigakis, T. Bartzanas, and E. Kitta. 2012. Effects on microclimate, crop production and quality of a tomato crop grown under shade nets. J. Hort. Sci. Biotechnol. 87:7-12, https:// doi.org/10.1080/14620316.2012.11512 822.

Klute, A. 1986. Methods of soil analysis. Part I: Physical and mineralogical properties. 2nd ed. Amer. Soc. Agron., Soil Sci. Amer., Madison, WI.

Meena, R.K., A. Vashisth, R. Singh, B. Singh, and K.M. Manjaih. 2014. Study on change in microenvironment under different color shade nets and its impact on yield of spinach (Spinacia oleracea). J. Agrometerol. 16:104-111.

Mohawesh, O., H. Al-Hamaiedeh, A. Balasmeh, S. Qaraleh, and M. Haddadin. 2019. Effect of olive mill wastewater (OMW) application on soil properties and wheat growth performance under rain-fed conditions. Water Air Soil Pollut. 230:160, https://doi.org/10.1007/s11270-0194208-8.

Mohawesh, O. 2016. Field evaluation of deficit irrigation on tomato growth performance, water use efficiency, and control of parasitic nematode infection. S. Afr. J. Plant Soil 33:125-133, https://doi.org/ 10.1080/02571862.2015.1096421.

Mohawesh, O. and M. Karajeh. 2014. Effects of deficit irrigation on tomato and eggplant and their infection with the rootknot nematode under controlled environmental conditions. Arch. Agron. Soil Sci. 60:1091-1102, https://doi.org/10.1080/ 03650340.2013 .871385 .
Möller, M. and S. Assouline. 2007. Effects of a shading screen on microclimate and crop water requirements. Irrig. Sci. 25: 171-181, https://doi.org/10.1007/s00 271-006-0045-9.

Mupambia, G., M.A. Brendon, R.L. Desmond, M. Stefano, S. Sara, S. Tory, and A.K. Lee. 2018. The influence of protective netting on tree physiology and fruit quality of apple: A review. Scientia Hort. 236:60-72, https://doi.org/10.1016/j. scienta.2018.03.014.

Ntsoane, M.L. 2015. Effect of photoselective nettings on plant growth, quality at harvest and after postharvest storage in lettuce varieties. M.Sc. Thesis, Tshwane Univ. Technol., Pretoria, South Africa.

Rylski, I. and M. Spigelman. 1986. Effect of shading on plant development, yield and fruit quality of sweet pepper grown under conditions of high temperature and radiation. Scientia Hort. 29:31-35, https://doi. org/10.1016/0304-4238(86)90028-2.

Sadasivam, S. and A. Manickam. 1992. Biochemical methods for agricultural sciences. lst ed. Wiley Eastern, New Delhi, India.

Shahak, Y. 2014. Photoselective netting: An overview of the concept, R\&D and practical implementation in agriculture. Acta Hort. 1015:155-162, https://doi.org/10.17660/ ActaHortic.2014.1015.17.

Shahak, Y., E.E. Gussakovsky, E. Gal, and R. Ganelevin. 2004. Color nets: Crop protection and light-quality manipulation in one technology. Acta Hort. 659:143-151, https://doi.org/10.17660/ActaHortic. 2004.659.17.

Stamps, R.H. 2009. Use of colored shade netting in horticulture. HortScience 44:239-241, https://doi.org/10.21273/ HORTSCI.44.2.239.

Tinyane, P.P., D. Sivakumar, and P. Soundy. 2013. Influence of photo-selective netting on fruit quality parameters and bioactive compounds in selected tomato cultivars. Scientia Hort. 161:340-349, https:// doi.org/10.1016/j.scienta.2013.06.024.

Watanabe, F.S. and S.R. Olsen. 1965. Test of an ascorbic acid method for determining phosphorus in water and $\mathrm{NaHCO}_{3}$ extracts from soil. Soil Sci. Soc. Amer. Proc. 29: 677-678, https://doi.org/10.2136/sssaj $1965.03615995002900060025 x$. 